\title{
International Conference on Dialogue of Civilizations
}

The International Conference on Dialogue of Civilizations was held in the heart of London, at the Islamic Centre of England in Maide Vale, October 27-28. A group of eminent scholars from several countries convened to participate and present their points of view on this quite important and popular subject: Dialogue of Civilizations!

The conference was hosted by the Institute of Islamic Studies of London (IIS) and sponsored by Shahid Beheshti University (Iran), Allame Tabataba'ee University (Iran), the Institute for Political and International Studies (Iran) and the Islamic College for Advanced Studies (United Kingdom). Several participants attended from local colleges and universities in and around London. Journalists from different organizations covered the event for newspaper and television. The two-day program, which included panel sessions, a play and a music section, was video-recorded and documented. Overall, the conference can certainly be regarded as a successful one, although, as in many other fora, there was room for improvement in few of its parts.

Implicit in the title of the project is a rather grand albeit a noble ambition: the reconciliation of civilizations that are on a colision course. In pursuing this lofty goal, participants came face-to-face with the difficulty of defining the concept of 'civilization' across civilizations. Perhaps it was this difficulty that contributed to the meeting's success, and helped participants discover how definitional problems can be overcome and how, indeed, understanding between conflicting entities can be achieved.

Most papers in the first panel, titled "Globalization," started with a rather rosy picture for possibilities of a dialogue. The second panel reversed the tone, while presenting several definitions of civilization, it questioned whether 'modern civilization' can be called a civilization at all. Some presentations tied the definition of civilization to its primordial religious tradition, thus disqualifying modern civilization as a civilization and characterizing it as anti-civilization. The third panel used Cultural Studies and 
Interfaith Dialogue as two points of reference in approaching the Dialogue of Civilizations. With three excellent presentations and a lively discussion afterwards, it highlighted the fact that Interfaith Dialogue, or rather Interfaith Understanding, is perhaps a better category of understanding than Dialogue of Civilizations. The detailed program of the conference can be found at http://www.islamic-studies.org/dialconfer.htm.

In his concluding remarks, Dr. Ezzati (director, the Islamic College for Advanced Studies, U.K.) challenged the notion of intercivilizational dialogue by asserting that there are no civilizations, but just one civilization, i.e., the Human Civilization. Dr. Ezzati's thesis added very important implications to this subject. If indeed there is only one civilization (or say, an idea of civilization that can be distilled from the essences of different civilizations), then what are these entities that are clashing with each other, given the fact that indeed there is a clash which is so evident at different flash points around the world, as identified by Sam Huntington? The conference at this turn, as in several others, was becoming a conference on "Islam \& the West" and "Battle between Modernism \& Tradition" rather than a conference on the Dialogue of Civlizations.

Perhaps the Conference was titled "Dialogue of Civilizations" because of President Khatami's suggestion to make the year 2001 the year of dialogue of civilizations. Also, the reason that the proposal of a dialogue came from the Muslim side is because Muslim civilization, which shows visible signs of rejuvination, is under pressure from all sides, geographical and ideological. Although the clash is most visible in contemporary times between the world of Islam and the secular West, there are other societies outside the scope of the Huntingtonian premonition of a "Sino-Islamic" threat, which could and should have been a part of this conference. The Chinese, Japanese, and Africans were surprisingly missing from the scene, as it was dominated only by the western and/or Muslim academics and journalists.

Iranian hospitality was as usual generous and excellent. All overseas guests were very well provided for and housed at the London Metropole Hilton, a short walk from the Islamic Centre. The conference venue was very good, as it provided the participants and speakers with a large hall and ample seating. The Islamic Centre of Maide Vale used to be a Cinema, which was bought and then converted into an Islamic Center. This provided a good ambience for presentations and performance, due to its good rear projection facility and first-class acoustics. The upstairs of the Islamic Centre had rooms for rest, prayer and food. Downstairs also had a restaurant with Persian food which was open for the conference guests. 
Besides the academic program of the conference, there was a modest book display, a short play, and performance of traditional Persian music from the Zor-Khane. The play, performed by young actors of the Youth Theater Workshop, was titled "The Day Daggers Broke Loose." It was based on the spiritual teachings of God's prophets, whose central message is love and friendship among mankind. It had no vocals, only lights and background music. The Youth Theatre Workshop was assisted by the Technical Department of the Islamic Centre of England. The play consisted of seven scenes titled: The Perfumed Clay of Creation; The Prison of Temptation; The Earth which is in Close Proximity to Heaven; From the Heart of Earth Springs Fertility; The One Who Tainted Humanity with Bloodshed; This is My Dagger and That is Your Chest; A Rider Came Carrying Justice. The final act ended with an eschatological theme that is common to the Abrahamic faiths: the darkness of oppression will be overcome by the light of justice, and humanity will put aside hatred when finally Heaven and Earth smile upon one another.

The Drama division, which was founded as part of the Research and Education Department of the Islamic Centre England, has made considerable efforts to preserve and revive Persian and Islamic Art by engaging in creative activity such as this.

After the play, very stimulating traditional Persian music was played by Morshed Mola'ee from Iran. The same group also played some more inspirational music of the Zor-Khane (literally translated as the "gymnasium"). It was interesting to note how the world of sports was integrated with spirituality in the traditional Iranian society. The presence of sacred music as the background to the exercises of the Zor-Khane illustrates that sports were not just a physical activity but also a spiritual one whose ultimate source of vigor and motivation is divine.

The Institute of Islamic Studies must be congratulated for putting together an excellent conference. IIS has been facilitating and coordinating research in the fields of Islamic history, literature, arts, culture, and civilization in close cooperation with the scholars who are actively engaged in quality research in these fields. It has also facilitated academic debates and discussions on issues that are thought to be highly important to the Muslim world and the Muslim communities living in the West. 